\title{
CHARACTERISTIC FEATURES OF THE OIL-HEAT TREATED WOODS FROM TROPICAL FAST GROWING WOOD SPECIES
}

\author{
Intan Fajar Suri, Byantara Darsan Purusatama, Seung Hwan lee, Nam Hun Kim \\ Kangwon National University \\ Republic Of Korea \\ Wahyu Hidayat, Shalehudin Denny Ma'ruf \\ University Of LAMPung \\ INDONESIA \\ Fauzi Febrianto \\ IPB UNIVERSITY \\ INDONESIA
}

(Received July 2020)

\begin{abstract}
This study aimed to evaluate the effect of oil-heat treatment on the anatomical, physical, and chemical properties of the tropical fast-growing wood species as gmelina (Gmelinaarborea) and mindi (Melia azedarach) wood. Vessel lumen area and diameter in radial and tangential direction of both species increased with increasing temperature. The fiber lumen areas in both woods were remarkably decreased by oil-heat treatment, and the fiber wall area increased considerably with increasing temperature. Both woods tended to gain weight after heat treatment at $180^{\circ} \mathrm{C}$ and $200^{\circ} \mathrm{C}$, and then lose weight after heat treatment at $220^{\circ} \mathrm{C}$. The density of mindi increased greatly at $180^{\circ} \mathrm{C}$ and $200^{\circ} \mathrm{C}$ and slightly decreased at $220^{\circ} \mathrm{C}$. The dimension of the specimens in tangential direction increased with heat treatment, but the rate decreased with increasing temperature. The relative crystallinity and crystallite width of the heat-treated woods were greater than those of the untreated wood. In the Fourier transform infrared analyses, the peaks from the carbohydrates were changed after oil-heat treatment, mainly due to the degradation of hemicellulose. Consequently, it was revealed that the heat treatment affected various properties of gmelina and mindi woods. Differing characteristics between the species were also noted.
\end{abstract}

KEYWORDS: Anatomical properties, chemical composition, Gmelinaarborea, Melia azedarach, oil-heat treatment, physical properties. 


\section{INTRODUCTION}

The potential supply and utilization of wood from plantation forests continue to increase. The wood harvested from plantation forests in Indonesia mostly belongs to fast-growing wood species as well as gmelina (Gmelinaarborea) and mindi (Melia azedarach). Gmelina has raised interest because of its rapid growth and rapid return on investment that can be used for many products ranging from pulp to furniture (Dvorak 2004). Mindi is considered as a fast-growth and drought-resistant species and widely used for construction, furniture, or interior decoration because it is quite durable and termite resistant (Bui et al. 2019). However, wood from most fast-growing species is generally low in quality, and its properties need to be improved, due to inferior quality with low density, low durability, and low mechanical properties, rendering them not suitable as structural materials(Febrianto et al. 2015).

Modification by heat treatment is one of the recent technologies used to improve some properties of woods (Biziks et al. 2013,Hidayat et al. 2016). Heat treatment of wood can be applied to achieve the desired improvement in dimensional stability and hydrophobicity (Tjeerdsma and Militz 2006), and biological durability (Welzbacher et al. 2008). Welzbacher et al. (2011) also reported that thermal treatment leads to substantial loss of the strength of heat-treated woods. Heat-treated wood also had lower equilibrium moisture content than untreated wood (Hidayat et al. 2015) and increased in hydrophobicity with increasing contact angle on wettability (Kocaefe et al. 2008). Meanwhile, heat treatment affects the anatomical structure of wood, as evidenced by the destruction of tracheid walls and ray tissues, as well as pit deaspiration (Awoyemi and Jones 2011), but this depends on the wood species, heat treatment process, and the conditions used (Boonstra et al. 2006).

With regard to cost, environmental-friendliness, and sustainability of chemistry, oil-heat treatment is considered one of the most practical approaches to eliminating the inferior features of wooden materials (Tang et al. 2019). Another related study on oil-heat treatment also explained that oil uptake also contributes to the dimensional stability and hydrophobicity (Wang and Cooper 2005) as well as fungal resistance and darkening (Dubey et al. 2011) of wood. Lee et al. (2018) demonstrated that oil-heat-treated wood showed superior dimensional stability to that of wood treated in hot air and nitrogen. Oil heat treatment can also be used to upgrade wood for outdoor uses and uniformly color its surface (Sailer et al. 2000).

To date, information on the improvement of the wood quality of fast-growing wood species using oil-heat treatment has been lacking. Therefore, in the present study, oil heat treatment was applied to improve the wood quality of two fast-growing wood species, gmelina and mindi, growing in Indonesia

\section{MATERIAL AND METHODS}

\section{Materials}

Gmelina (Gmelinaarborea) and Mindi (Melia azedarach) woods were harvested from PerumPerhutaniKesatuanPemangkuanHutan (KPH) Bogor and KPH Purwakarta in Java, Indonesia. Logs of woods were converted into quarter-sawn boards with dimensions of $200 \mathrm{~mm}(\mathrm{~L})$ x $90 \mathrm{~mm}$ (R) x $20 \mathrm{~mm}$ (T). Boards were selected that were free of natural defects and straight grain. Then the selected boards were air-dried and conditioned at $25^{\circ} \mathrm{C} \pm 5^{\circ} \mathrm{C}$ under a relative humidity of $70-80 \%$ until they reached the equilibrium moisture content. 


\section{Methods}

\section{Oil-heat treatment}

Boards were heat-treated in a lab-scale oil bath using commercial cooking palm oil. The heat treatment was started at an initial temperature of $25^{\circ} \mathrm{C}-30^{\circ} \mathrm{C}$. The temperature was then raised to the target of $180^{\circ} \mathrm{C}, 200^{\circ} \mathrm{C}$, and $220^{\circ} \mathrm{C}$ at the rate of $2^{\circ} \mathrm{C} \cdot \mathrm{min}^{-1}$. The target temperature was maintained over a period of $1 \mathrm{~h}$. In the final stage of heat treatment, the oil bath was allowed to cool naturally until it reached $\pm 30^{\circ} \mathrm{C}$. The boards were then taken out and stored in a room with the relative humidity of $70-80 \%$ and a temperature of $25 \pm 5^{\circ} \mathrm{C}$ for two weeks until further testing.

\section{Scanning electron microscopy}

The smooth transversal section of the block with a dimension of $10 \mathrm{~mm}(\mathrm{~L}) \times 10 \mathrm{~mm}(\mathrm{~T}) \mathrm{x}$ $10 \mathrm{~mm}(\mathrm{R})$ was prepared with a microtome, and then oven-dried and a Cressington sputter coater (ULVAC G-50DA, Japan) used to coat the sample. Microscopic observation was performed with a scanning electron microscope (JSM-5510, JEOL, Japan, 15kV). The micrographs of each sample were analyzed for measuring vessel lumen area $\left(\mu \mathrm{m}^{2}\right)$, diameter of vessel lumen in the radial $(\mathrm{RD})$ and tangential $(\mathrm{TD})$ direction $(\mu \mathrm{m})$, fiber lumen area $\left(\mu \mathrm{m}^{2}\right)$, and fiber wall area $\left(\mu \mathrm{m}^{2}\right)$. The measurements for each parameter were examined 90 times. The change of cell lumen area in vessel and fiber was calculated using the following formula (Biziks et al. 2013):

$$
\operatorname{SEM}(\%)=\frac{S E M_{1}-S E M_{0}}{S E M_{0}} \times 100
$$

where: SEM (\%) is the change in the cell lumen area in the vessel and the fiber (\%), $\mathrm{SEM}_{1}$ is the cell lumen area after heat treatment, and $\mathrm{SEM}_{0}$ is the cell lumen area before heat treatment. Measurements were performed using the freely-available ImageJ software package (University of Wisconsin, Madison, USA).

\section{Measurements of physical properties}

Weight change before and after the heat treatment was intended according to the following formula:

$$
W C(\%)=\frac{m_{1}-m_{0}}{m_{0}} \times 100
$$

where: $\mathrm{m}_{0}$ is the weight of samples before oil-heat treatment $(\mathrm{g})$ and $\mathrm{m}_{1}$ is the weight of samples after oil-heat treatment $(\mathrm{g})$. Density (D) of samples before and after heat treatment was intended according to the following formula:

$$
D=\frac{m}{v}
$$

where: $\mathrm{m}$ is the weight $(\mathrm{g})$ and vis the volume of samples $\left(\mathrm{cm}^{3}\right)$. Swelling in tangential direction of samples before and after heat treatment was intended according to the following formula:

$$
S(\%)=\frac{S_{1}-S_{0}}{S_{0}} \times 100
$$

where: $S_{0}$ is the swelling of samples before oil-heat treatment $(\mathrm{mm})$ and $\mathrm{S}_{1}$ is the swelling of samples after oil-heat treatment $(\mathrm{mm})$. Three samples were measured for each physical property after each treatment and mean values were determined.

\section{Crystalline characteristic analyses}

An X-ray diffractometer (DMAX2100V, Rigaku, Tokyo, Japan) was used to measure crystalline characteristics as relative crystallinity and crystallite width. Segal's equation 
(Segal et al. 1959) was used to calculate the relative crystallinity:

$$
\text { Relative crystallinity }=\frac{I_{200}-I_{a m}}{I_{200}} \times 100
$$

where: $\mathrm{I}_{200}$ is the diffraction intensity of $(200)\left(2 \theta=22.8^{\circ}\right)$ and $\mathrm{I}_{\mathrm{am}}$ is the diffraction intensity of the non-crystalline portion $\left(2 \theta=18^{\circ}\right)$. The crystallite width was calculated using the Scherer's equation (Burton et al. 2009):

$$
L=\frac{K \lambda}{\beta \cos \theta}
$$

where: $\mathrm{L}$ is the crystallite width, $\mathrm{K}$ is the Sherrer constant $(0.9), \lambda$ is the $\mathrm{X}$-ray wave length $(\lambda=0.1542 \mathrm{~nm})$, and $\beta$ is half-width in radians. Three samples were measured for each treatment and average values were determined.

\section{Chemical composition analyses}

To investigate the chemical composition of gmelina and mindi woods before and after oil-heat treatment, wood powders for each treatment were prepared. The spectra were measured using the attenuated total reflection (ATR) method in the range of $4000-400 \mathrm{~cm}^{-1}$ with Fourier transform infrared spectrometer (Perkin Elmer Inc., USA) set in the main laboratory of Kangwon National University.

\section{Statistical analysis}

All multiple comparisons were analyzed with multivariate analysis of variance. Significant $(\alpha \leq 0.05)$ differences between values of the untreated and treated samples were determined using Duncan's multiple range tests. All statistics were performed using SPSS ver. 24, IBM Corp., New York, USA.

\section{RESULTS AND DISCUSSION}

\section{Anatomical properties}

As shown in Tab. 1, the vessel lumen area and diameter of vessel lumen in a radial (RD) and tangential (TD) direction increased with increasing temperature. Gmelina wood increased up to $5.6 \%$ in the vessel lumen area and $24.7 \%$ and $18.3 \%$ in the diameter of vessel lumen in radial and tangential directions, respectively, at $220^{\circ} \mathrm{C}$. While in mindi wood, there was an increase of up to $59.9 \%$ in vessel lumen area, $37.4 \%$ in the radial diameter, and $17.1 \%$ in the tangential diameter of vessel lumen at $220^{\circ} \mathrm{C}$. Comparing both species, it can be explained that mindi wood showed a greater change in the dimension of the vessel than in gmelina wood during heat treatment. Fig. 1 shows the vessels on the transverse section of the gmelina and mindi woods with the same magnification before and after oil-heat treatment; the vessel dimension in both the wood species increased with heat treatment. Batista et al. (2015) reported that the vessel diameter of Eucalyptus grandis wood increased after heat treatment at $140^{\circ} \mathrm{C}$, but this increase was not significant. However, Biziks et al. (2013) reported opposite results, that in Betula pendula, lumen area and diameter of the vessels slightly decreased, and the wall area and wall thickness of the vessels considerably decreased after hydrothermal treatment. A significant change in fiber dimension was observed, as shown in Tab. 1. The fiberlumen area of gmelinawooddecreased by $36.2 \%$, fiberwallareaincreasedby $60.1 \%$, andfiber total area decreased by $1.37 \%$ at $220^{\circ} \mathrm{C}$. The fiber lumen area in mindi greatly decreased by $61.9 \%$, the fiber wall area increased by $61.1 \%$, and fiber total area decreased by $11.58 \%$ at $220^{\circ} \mathrm{C}$. The fiber lumen area and fiber total area decreased, while the fiber wall area increased with increasing temperature. This shows that the fiber wall swelled as a result of oil uptake during heat treatment and that the heat temperature affected the swelling of the cell wall. Scanning 
electron micrographs of the fibers of gmelina and mindi before and after oil-heat treatment are shown in Fig.2. The fiber lumen area of the treated wood clearly decreased to less than that of the untreated wood, but the fiber wall area increased with increasing temperature. Ling et al. (2016) reported similar results in Populuscathayaha sapwood, in which the fiber walls thickened and fiber lumen size shrank during and after heat treatment. Biziks et al. (2013) observed structural changes in Betula pendula wood: the fiber lumen area, fiber total area, and fiber wall area decreased during hydrothermal treatment. They described that the degradation of hemicelluloses in cell wall, which is known as the most unstable wood component, causes the change in cell dimension by heat treatment. Awoyemi and Jones (2011) also explained that changes in wood anatomy might be affected by wood properties with chemical degradation during the process of heat treatment. In this study, the oil-heat treatment led to anatomical changes in the wood cells. This phenomenon could be explained as follows: (1) The cell wall in the wood fiber and vessel might be softened and become more flexible following oil uptake, (2) The increased size of the vessel lumen can also be attributed to the tension force induced by the change of fiber dimension in the swollen state due to oil uptake, (3) The space created due to changes in fiber dimensions allowed the vessel dimension to increase in oil-heat-treated wood as compared to that of untreated wood. Bernabei and Salvatici (2016) demonstrated that the tracheid cell dimensions decreased, but in certain cases, it increased after treatment, because of the power given to the lumen by surrounding cells. Boonstra et al. (2006) also explained that the dimensions of vessels and rays were changed due to the contraction of the cell walls and the shrinkage of the surrounding cells, such as the wood fibers or tracheid.

Tab. 1: Dimensional changes in vessels and fibers before and after oil-heat treatment.

\begin{tabular}{|c|c|c|c|c|c|c|c|}
\hline \multirow[b]{2}{*}{$\begin{array}{l}\text { Wood } \\
\text { species }\end{array}$} & \multirow{2}{*}{$\begin{array}{c}\text { Cell type } \\
\text { Measurements }\end{array}$} & \multicolumn{3}{|c|}{ Vessel } & \multicolumn{3}{|c|}{ Fiber } \\
\hline & & $\begin{array}{l}\text { Lumen area } \\
\qquad\left(\mu \mathrm{m}^{2}\right)\end{array}$ & $\begin{array}{c}\mathrm{RD} \\
(\mu \mathrm{m})\end{array}$ & $\begin{array}{l}\text { TD } \\
(\mu \mathrm{m})\end{array}$ & $\begin{array}{l}\text { Lumen area } \\
\qquad\left(\mu \mathrm{m}^{2}\right)\end{array}$ & $\begin{array}{c}\text { Wall area } \\
\left(\mu \mathrm{m}^{2}\right)\end{array}$ & $\begin{array}{c}\text { Total area of } \\
\text { fiber } \\
\left(\mu \mathrm{m}^{2}\right)\end{array}$ \\
\hline Gmelina & Initial sizes & 11455 (1524) & $112.1(1.53)$ & $92.2(3.30)$ & $97.6(1.74)$ & $59.4(4.74)$ & $158(2.45)$ \\
\hline \multirow[t]{2}{*}{ Mindi } & Initial sizes & $24126(7008)$ & $164.6(3.72)$ & 143.5 (1.52) & $87.7(1.18)$ & $61.4(1.59)$ & $149(1.47)$ \\
\hline & $\begin{array}{c}\text { Temperature } \\
\left({ }^{\circ} \mathrm{C}\right)\end{array}$ & \multicolumn{6}{|c|}{ Changes (\%) } \\
\hline Gmelina & $\begin{array}{l}180 \\
200 \\
220 \\
\end{array}$ & $\begin{array}{l}2.3(2.28) \\
4.9(2.35) \\
5.6(2.39)\end{array}$ & $\begin{array}{l}14.4(3.82) \\
23.2(3.33) \\
24.7(2.10)\end{array}$ & $\begin{array}{c}4.7(2.70) \\
10.1(5.24) \\
18.3(2.51)\end{array}$ & $\begin{array}{l}-2.2(1.32) \\
-23.0(0.55) \\
-36.2(0.65)\end{array}$ & $\begin{array}{c}1.6(3.24) \\
37.0(1.52) \\
60.1(3.94)\end{array}$ & $\begin{array}{l}-0.84(1.73) \\
-0.86(1.15) \\
-1.37(3.74)\end{array}$ \\
\hline Mindi & $\begin{array}{l}180 \\
200 \\
220\end{array}$ & $\begin{array}{l}19.0(7.53) \\
30.7(3.81) \\
59.9(6.92) \\
\end{array}$ & $\begin{array}{l}19.9(4.05) \\
24.6(1.52) \\
37.4(4.65)\end{array}$ & $\begin{array}{c}1.2(3.72) \\
13.7(6.08) \\
17.1(2.64)\end{array}$ & $\begin{array}{l}-12.9(1.16) \\
-34.5(2.58) \\
-61.9(6.14)\end{array}$ & $\begin{array}{l}12.5(1.11) \\
42.5(1.76) \\
61.1(2.75)\end{array}$ & $\begin{array}{c}-2.39(1.98) \\
-2.75(2.02) \\
-11.58(2.65)\end{array}$ \\
\hline
\end{tabular}

Notes: The numbers in parenthesis are the standard deviations. RD: diameter of vessel in radial direction, TD: diameter of vessel in tangential direction.
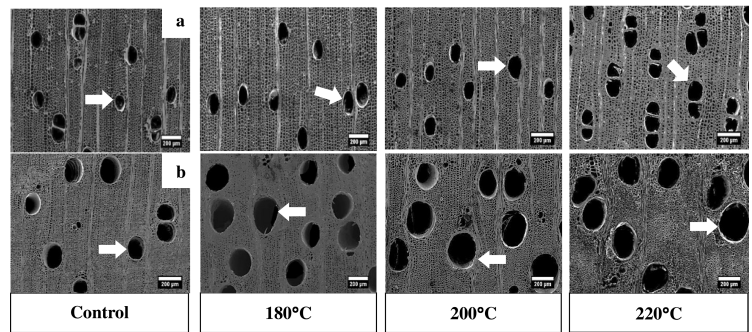

Fig.1: Vessels on the transverse sections of gmelina (a) and mindi (b) before and after oil-heat treatment. White arrows indicate the change in vessel lumen size before and after oil-heat treatment. Scale bars: $200 \mu \mathrm{m}$. 


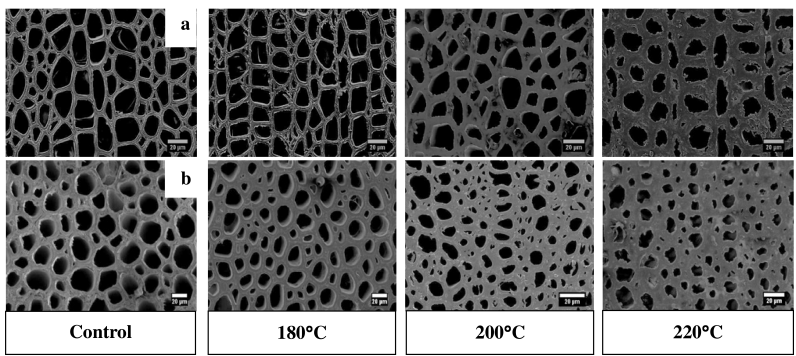

Fig.2: Fibers on the transverse sections of gmelina (a) and mindi (b) before and after oil-heat treatment. Scale bars: $20 \mu \mathrm{m}$.

\section{Physical properties}

The physical properties of gmelina and mindi woods before and after oil-heat treatment are shown in Tab. 2. A higher degree of weight change was observed in mindi, showing a great increase in the weight after heat treatment at $180^{\circ} \mathrm{C}$ and $200^{\circ} \mathrm{C}$ and a decrease in the weight at $220^{\circ} \mathrm{C}$. Gmelina wood gained weight slightly at $180^{\circ} \mathrm{C}$ and $200^{\circ} \mathrm{C}$ and rapidly lost weight at $220^{\circ} \mathrm{C}$. This result agreed with the study conducted by Dubey et al. (2011) that observed an increase in specimen weight due to oil absorption during heat treatment and a weight decrease with increasing temperature and time. Sailer et al. (2000) also reported that the weight of Pinussylvestris and Piceaabies increased by about $50 \pm 70 \%$ after oil-heat treatment. Dubey et al. (2011) also stated that the weight decrease after heat treatment indicated the change of chemical composition in wood, particularly, the degradation of the hemicellulose content up to 70\%. Hidayat et al. (2015) and Mburu et al. (2007) also explained that the weight loss of wood was due to the degradation of hemicelluloses during heat treatment.

Tab. 2: Weight change, density, and swelling after heat treatment.

\begin{tabular}{|c|c|c|c|c|}
\hline Wood species & $\begin{array}{c}\text { Temperature } \\
\left({ }^{\circ} \mathrm{C}\right)\end{array}$ & $\begin{array}{l}\text { Weight change* } \\
(\%)\end{array}$ & $\begin{array}{l}\text { Density } \\
\left(\mathrm{g} \cdot \mathrm{cm}^{-3}\right)\end{array}$ & $\begin{array}{l}\text { Swelling in tangential } \\
\text { direction } \\
(\%)\end{array}$ \\
\hline Gmelina & $\begin{array}{c}\text { Control } \\
180 \\
200 \\
220\end{array}$ & $\begin{array}{c}- \\
1.98(0.02) \\
2.50(0.06) \\
-5.73(1.04)\end{array}$ & $\begin{array}{l}0.43(0.02) \\
0.45(0.01) \\
0.43(0.01) \\
0.42(0.02)\end{array}$ & $\begin{array}{c}- \\
3.46(0.65) \\
2.32(0.58) \\
2.09(0.29)\end{array}$ \\
\hline Mindi & $\begin{array}{l}\text { Control } \\
180 \\
200 \\
220\end{array}$ & $\begin{array}{c}- \\
24.61(4.38) \\
15.03(0.98) \\
-7.39(0.74)\end{array}$ & $\begin{array}{l}0.51(0.03) \\
0.66(0.02) \\
0.59(0.02) \\
0.48(0.01)\end{array}$ & $\begin{array}{c}- \\
5.77(1.36) \\
4.20(1.02) \\
0.66(1.06)\end{array}$ \\
\hline
\end{tabular}

Note: "minus (-) values mean weight loss and vice versa. The numbers in parenthesis are the standard deviations.

The density of mindi wood after heat treatment was changed as shown in Tab. 2. The density increased greatly at $180^{\circ} \mathrm{C}$ and $200^{\circ} \mathrm{C}$ and slightly decreased at $220^{\circ} \mathrm{C}$. However, the density of gmelina wood before and after treatment was scarcely changed. Wang et al. (2014) observed similar result as the density of Eucalyptus pellita wood decreased slowly with increasing the temperature at $200^{\circ} \mathrm{C}$ and $240^{\circ} \mathrm{C}$. They stated the two possible factors for the decrease in density during heat treatment as the degradation of hemicellulose and volatile components. 
The specimen's thickness in tangential direction increased with heat treatment as shown in Tab. 2. The degree of swelling decreased with increasing temperature. The woods treated at $220^{\circ} \mathrm{C}$ appeared more stable than those treated treated at $180^{\circ} \mathrm{C}$ and $200^{\circ} \mathrm{C}$. This result agreed with the study of $\mathrm{Bal}$ (2015) that the swelling values of wood treated with oil-heat treatment decreased with increasing temperature. Lee et al. (2018) stated that oil absorption and oil deposits in the cell walls of wood also act as factors, which contribute to the improvement of the dimensional stability of wood.

\section{Crystalline characteristics}

The relative crystallinityof the heat-treated woods was slightly larger than that of the untreated woods, as shown in Tab. 3. It could be suggested that the relative crystallinity increased with heat treatment. Kim et al. (2018) reported that heat treatment increased the relative crystallinity of Paulownia wood. Yun et al. (2015) also reported that the relative crystallinity of Eucalyptus urophylla and E. camaldulensis increased as the temperature increased. The increase in crystallinity can probably be attributed to the degradation of hemicelluloses and the realignment of cellulose (Tang et al. 2019).

Tab 3: Crystalline properties of gmelina and mindi woods before and after oil-heat treatment.

\begin{tabular}{|l|c|c|c|}
\hline Wood species & $\begin{array}{c}\text { Temperature } \\
\left({ }^{\circ} \mathbf{C}\right)\end{array}$ & $\begin{array}{c}\text { Relative crystallinity } \\
\mathbf{( \% )}\end{array}$ & $\begin{array}{c}\text { Crystallite width } \\
\text { ( } \mathbf{n m})\end{array}$ \\
\hline \multirow{4}{*}{ Gmelina } & Control & $57.3^{\mathrm{a}}(1.5)$ & $2.69^{\mathrm{a}}(0.14)$ \\
& 180 & $58.2^{\mathrm{a}}(3.4)$ & $2.4^{\mathrm{a}}(0.16)$ \\
& 200 & $60.9^{\mathrm{b}}(1.7)$ & $2.7^{\mathrm{a}}(0.14)$ \\
& 220 & $69.3^{\mathrm{c}}(0.5)$ & $3.22^{\mathrm{b}}(0.11)$ \\
\hline \multirow{3}{*}{ Mindi } & Control & $57.8^{\mathrm{a}}(2.8)$ & $2.85^{\mathrm{a}}(0.07)$ \\
& 180 & $58.4^{\mathrm{a}}(2.0)$ & $2.91^{\mathrm{a}}(0.14)$ \\
& 200 & $61.4^{\mathrm{b}}(2.0)$ & $3.03^{\mathrm{a}}(0.28)$ \\
& 220 & $68.5^{\mathrm{c}}(2.3)$ & $3.45^{\mathrm{b}}(0.38)$ \\
\hline
\end{tabular}

Note: The numbers in parenthesis are the standard deviations. The different letters beside the mean value show the significance at $5 \%$ level between untreated and treated wood using Duncan's multiple range tests.

The heat-treated woods showed slightly larger crystallite width than that of the untreated one, as shown in Tab. 3. It seems that the crystallite width could be increased after oil-heat treatment. Kubojima et al. (1998) also reported that the crystallite length of the heat-treated Sitka spruce seemed to be increased. The same tendency was also observed by Andersson et al. (2005), stating that the increase in the size of cellulose crystallites was due to the changes in porosity of the cell wall by the degradation of the amorphous part of wood during heat treatment.

\section{Chemical composition analyses}

Fig.3 shows the FTIR spectra of gmelina and mindi before and after oil-heat-treatment, and the appropriate peak assignment is summarized in Tab. 4. The spectral differences before and after oil-heat treatment were more considerable for mindi wood than for gmelina wood. The heat-treated wood showed the decreased characteristics of carbohydrates as compared to the untreated wood. The peak at $1740 \mathrm{~cm}^{-1}$ corresponding $\mathrm{C}=\mathrm{O}$ stretch decreased greatly in both gmelina and mindi with increasing temperature. Lin et al. (2018) reported that the peaks at $1730-1740 \mathrm{~cm}^{-1}$ of poplar and fir wood decreased with increasing temperature. They explained that the decrease was caused by the cleavage of acetyl side chains of hemicellulose 
after heat treatment. Ling et al. (2016) also reported that the peak at $1740 \mathrm{~cm}^{-1}$ on heat-treated Populuscathayaba wood decreased. Similarly, Cheng et al. (2016) reported that the peak at $1734 \mathrm{~cm}^{-1}$ of Chinese fir wood changed slightly at $190^{\circ} \mathrm{C}$ and considerably decreased at $230^{\circ} \mathrm{C}$. Esteves et al. (2013) also reported that the peaks at $1740 \mathrm{~cm}-1$ assigned to the division of acetyl or acetoxy groups in xylan of eucalypt wood decreased, showing the degradation of hemicelluloses. The peak at the range of 1105 and $1050 \mathrm{~cm}^{-1}$, corresponding to C-O-C stretching in cellulose and hemicellulose, in mindi also slightly decreased at $220^{\circ} \mathrm{C}$. Mburu et al. (2007) reported that the peaks at $1058 \mathrm{~cm}^{-1}$ in heat-treated Grevillea robusta wood slightly decreased as temperature increased. They also stated that the decrease of the band confirmed the degradation of hemicelluloses.
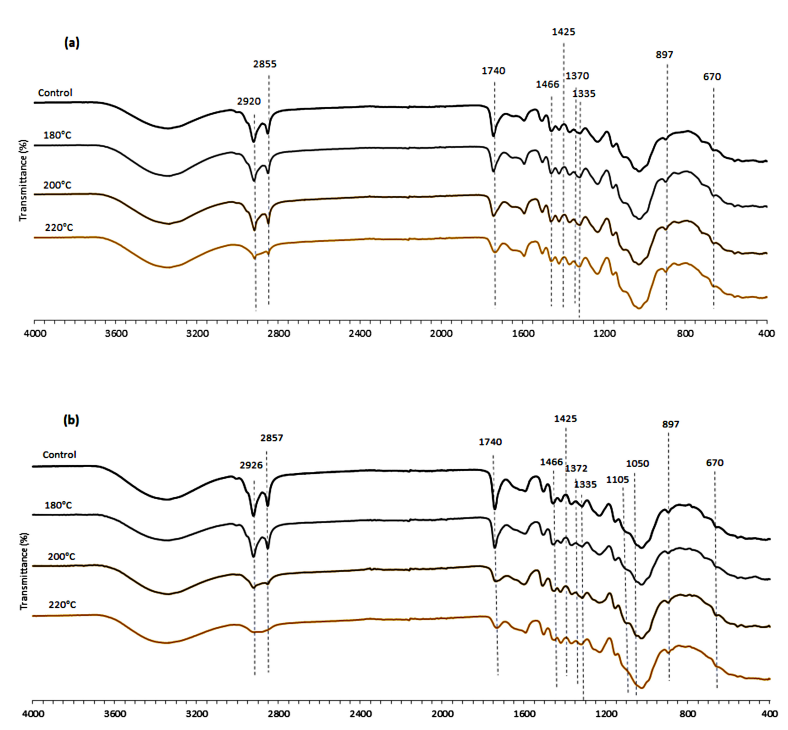

Fig. 3: FTIR spectra of gmelina (a) and mindi (b) wood before and after oil-heat treatment.

Tab. 4: Peak assignment for FTIR spectra of gmelina and mindi before and after oil-heat treatment.

\begin{tabular}{|c|c|}
\hline $\begin{array}{l}\text { Wave number } \\
\left(\mathrm{cm}^{-1}\right)\end{array}$ & Peak assignment \\
\hline 2926 & C-H stretching in cellulose (Esteves et al. 2013, Schwanninger et al. 2004) \\
\hline 2857 & \\
\hline 1740 & $\begin{array}{l}\mathrm{C}=0 \text { stretch (unconjugated) in esters, ketones, aldehydes and acids (Esteves et al. } \\
\text { 2013, Schwanninger et al. 2004, Lin et al. 2018) }\end{array}$ \\
\hline 1466 & $\begin{array}{l}\mathrm{C}-\mathrm{H} \text { deformations; asymmetric in }-\mathrm{CH}_{3} \text { and }-\mathrm{CH}_{2}-\text { (Huang et al. 2012, } \\
\text { Schwanninger et al. 2004) }\end{array}$ \\
\hline 1425 & $\begin{array}{l}\text { Aromatic skeletal vibrations (lignin) and C H deformation in plane (cellulose) } \\
\text { (Schwanninger et al. 2004) }\end{array}$ \\
\hline 1372 & C H deformation in cellulose and hemicellulose (Schwanninger et al. 2004) \\
\hline 1105 & $\mathrm{C}-\mathrm{O}-\mathrm{C}$ stretching in cellulose and hemicellulose (Traoré et al. 2018) \\
\hline 1050 & C-O stretching of secondary alcohols (Mburu et al. 2007, Traoré et al. 2018) \\
\hline 897 & C H deformation in cellulose (Schwanninger et al. 2004) \\
\hline 670 & C-OH out-of-plane bending mode (Schwanninger et al. 2004) \\
\hline
\end{tabular}


In addition to the characteristics of carbohydrates, heat-treated wood and untreated wood were also pronounced well by the peak of lignin at $1466 \mathrm{~cm}^{-1}$. The peak in gmelina and mindi decreased scarcely as the temperature increased. It indicates that lignin is also degraded by heat treatment, but the rate of degradation is much less than that of the hemicelluloses. Huang et al. (2012) reported that the peak at $1465 \mathrm{~cm}^{-1}$ in jack pine wood decreased after heat treatment and weathering. Cheng et al. (2013) also reported that the peak at $1462 \mathrm{~cm}^{-1}$ in moso bamboo decreased after being heat-treated with three aqueous solutions.

The cellulose crystallinity was also determined using different IR crystallinity ratios. There are two methods to determine the crystallinity, i.e., the first is the ratio of peak areas $A 1370 / A 670$, and the second is the ratio of peak heights at H1429/H897 and at H1372/H2900 (Åkerholm et al. 2004). Tab. 5 summarizes the result of the measurements.

Tab. 5: Cellulose crystallinity of gmelina and mindi using different $I R$ peak ratios.

\begin{tabular}{|c|c|c|c|c|}
\hline \multirow{2}{*}{ Wood species } & Temperature & \multicolumn{3}{|c|}{ IR peak ratio } \\
\cline { 3 - 5 } & $\left.{ }^{\circ} \mathbf{C}\right)$ & $\boldsymbol{A}_{\mathbf{1 3 7 0}} / \boldsymbol{A}_{\mathbf{6 7 0}}$ & $\boldsymbol{H}_{\mathbf{1 4 2}} / \boldsymbol{H}_{\mathbf{8 9 7}}$ & $\boldsymbol{H}_{\mathbf{1 3 7 2}} / \boldsymbol{H}_{\mathbf{2 9 0 0}}$ \\
\hline Gmelina & Control & 7.50 & 1.67 & 0.14 \\
& 180 & 8.33 & 1.75 & 0.19 \\
& 200 & 8.80 & 2.00 & 0.20 \\
& 220 & 8.93 & 1.60 & 0.55 \\
\hline Mindi & Control & 8.05 & 1.25 & 0.12 \\
& 180 & 8.25 & 1.00 & 0.14 \\
& 200 & 8.46 & 1.67 & 0.58 \\
& 220 & 8.48 & 1.50 & 0.60 \\
\hline
\end{tabular}

The ratio of the peak areas $(A 1370 / A 670)$ at 1370 and $670 \mathrm{~cm}^{-1}$ increased with increasing temperature in gmelina wood whereas the rate increased slightly in mindi wood. Then the values of $H 1429 / H 897$ and $H 1372 / H 2900$ showed a tendency to increase with increasing temperature in both species. These results indicate that the crystallinity of both woods increased as temperature increased. It is well matched with the result of X-ray diffraction analyses. Akgül et al. (2016) reported that the crystallinity in Pinussylvestris and Abiesnordmanniana wood increased after heat treatment. They explained that the increase in crystallinity might be due to the re-crystallization of cellulose molecules in quasi-crystalline amorphous region. Yildiz and Gümüskaya (2007) reported that all of the IR peak ratios in spruce and beech woods increased with increasing temperature from 150 to $200^{\circ} \mathrm{C}$.

\section{CONCLUSIONS}

The oil-heat treatment process of gmelina and mindi wood were investigated to clarify their characteristics before and after treatment. The vessel lumen area and diameter in radial and tangential direction increased with increasing temperature. The fiber lumen area and the fiber total area decreased and the fiber wall area increased with increasing temperature. Oil heat-treatment at $180^{\circ} \mathrm{C}$ and $200^{\circ} \mathrm{C}$ led to considerable weight gain for mindi wood but only slight weight gain for gmelina wood. Both wood species lost weight after treatment at $220^{\circ} \mathrm{C}$. The dimensions of specimens in tangential direction were increased by the oil-heat treatment. The degree of swelling decreased with increasing temperature. The relative crystallinity of the heat-treated woods was measured by the XRD and FTIR methods increased with 
increasing temperature. In FTIR analyses, the peaks from carbohydrate changed after the oil-heat treatment, mainly due to the dęrradation of hemicellulose.In this study, there were considerable changes in the anatomical, $\mathrm{F}$ hysical, and chemical properties of both wood species after the oil-heat treatment. Mindi wool showed greater changes in the properties than that of gmelina. The results suggest that in the orocess of heat treatment, species characteristics may be important for the evaluation of the final products.

\section{ACKNOWLEDGMENT}

This research was supported by the Basic Science Research Program through the National Research Foundation of Korea (NRF) which is funded by the Ministry of Education (NRF-2016R1D1A1B01008339), Basic Science Research Program through NRF funded by the Ministry of Education (NRF-2018R1A6A1A03025582) and Science and Technology Support Program through the Nitional Research Foundation of Korea (NRF) and funded by the Ministry of Science and ICT (MSIT) (NRF-2019K1A3A9A01000018). This research was also supported by the Indonesian Ministry of Research, Technology, and Higher Education through Post-Doctoral Research Grant in 2019 (Contract No. 065/SP2H/ LT/DRPM/2019).

\section{REFERENCES}

1. Akgül, M., Gümüskaya, E., Korkut, S., 2007: Crystalline structure of heat-treated Scots pine (Pinussylvestris L.) and Uludag fir (Abiesnordmanniana (Stev.) subsp. Bormuelleriana (Mattf.)) wood. Wood Science and Technology 41: 281-289.

2. Andersson, S., Serimaa, R., Vaananen, T., Paakkari, T., Jamsa, S., Viitaniemi, P., 2005: $\mathrm{X}$-ray scattering studies of thermally modified Scots pine (Pinussylvestris L.). Holzforschung 59: 422-427.

3. Awoyemi, L., Jones, P.I., 2011: Anatomical explanations for the changes in properties of western red cedar (Thujaplicata) wood during heat treatment. Wood Science and Technology 45: 261-267.

4. Åkerholm, M., Hinterstoisser, B., Salmén, L., 2004: Characterization of the crystalline structure of cellulose using static and dynamic FT-IR spectroscopy. Carbohydrate Research 339: 569-578.

5. Bal, B.C., 2015: Physical properties of beech wood thermally modified in hot oil and in hot air at various temperatures.Maderas. Ciencia y tecnología 17(4): $789-798$.

6. Batista, D.J., Paes, J.B., Muniz, G.I.B.D., Nisgoski, S., Oliveira, J.T.D.S., 2015: Microsturctural aspects of thermally modified Eucalyptus grandis wood. Maderas. Ciencia y tecnologia 17(3): 525-532.

7. Bernabei, M., Salvatici, M.C., 2016: In situ ESEM observations of spruce wood (Piceaabies Karst.) during heat treatment. Wood Science andTechnology 50: 715-726.

8. Biziks, V., Andersons, B., Belkova, L., Kapaca, E., Militz, H., 2013: Changes in the microstructure of birch wood after hydrothermal treatment. Wood Science and Technology 47: 717-735.

9. Boonstra, M.J., Rijsdijk, J.F., Sander, C., Kegel, E., Tjeerdsma, B.F., Militz, H., Van, A.J., Stevens, M., 2006: Microstructural and physical aspects of heat treated wood. Part 1. softwoods. Maderas. Cienca y tecnología 8: 193-208. 
10. Bui, T.P., Ly, L.K., Do, P.T., Nguyen, N.H., Nguyen, P.V., Tran, Q.H., Pham, N.B., Chu, H.H., 2019: Improvement of biomass production in transgenic Melia azedarach L. plants by the expression of a GA20-oxidase gene. Turkish Journal of Botany 43: 281-289.

11. Burton, A.W., Ong, K., Rea, T., Chan, I.Y., 2009: On the estimation of average crystallite size of zeolites from the Scherrer equation: A critical evaluation of its application to zeolites with one-dimensional pore systems. Microporous and Mesoporous Materials 117(1): 75-90.

12. Cheng, S., Huang, A., Wang, S., Zhang, Q. 2016: Effect of different heat treatment temperatures on the chemical composition and structure of Chinese fir wood. BioResources 11(2): 4006-4016.

13. Cheng, D., Jiang, S., Zhang, Q. 2013: Effect of hydrothermal treatment with different aqueous solutions on the mold resistance of moso bamboo with chemical and FTIR analysis. BioResources 8(1): 371-382.

14. Dubey, M.K., Pang, S., Walker, J., 2013: Changes in chemistry, color, dimensional stability and fungal resistance of Pinusradiata D. Don wood with oil heat-treatment. Holzforchung 66(1): 49-57.

15. Dvorak, W.S., 2004: World view of Gmelinaarborea: opportunities and challenges. New Forest 28: 111-126.

16. Esteves, B., Marques, A.V., Domingos, I., Pereira, H., 2013: Chemical changes of heat treated pine and eucalypt wood monitored by FTIR. Maderas. Cienc y tecnología 15: 245-258.

17. Febrianto, F., Pranata, A.Z., Septiana, D., Arinana, Gumilang, A., Hidayat, W., Jang, J.H., Lee, S.H., Hwang, W.J., Kim, N.H., 2015: Termite resistance of the less known tropical woods species grown in West Java, Indonesia. Journal of the Korean Wood Science and Technology 43(2): 248-257.

18. Hidayat, W., Jang, J.H., Park, S.H., Qi, Y., Febrianto, F., Lee, S.H., Kim, N.H., 2015: Effect of temperature and clamping during heat treatment on physical and mechanical properties of okan (Cylicodiscusgabunensis (Taub.) Harms) wood. BioResources 10(4): 6961-6974.

19. Hidayat, W., Qi, Y., Jang, J.H., Febrianto, F., Lee, S.H., Kim, N.H., 2016: Effect of treatment duration and clamping on the properties of heat-treated Okan wood. BioResources 11(4): 10070-10086.

20. Huang, X., Kocaefe, D., Kocaefe, Y., Boluk, Y., Pichette, A., 2012: Changes in wettability of heat-treated wood due to artificial weathering. Wood Science and Technology 46: 1215-1237.

21. Kim, Y.K., Kwon, G.J., Kim, A.R., Lee, H.S., Purusatama, B.D., Lee, S.H., Kang, C.W., Kim, N.H., 2018: Effects of heat treatment on the characteristics of royal paulownia (Paulownia tomentosa (Thunb.) Steud.) wood grown in Korea. Journal of the Korean Wood Science and Technology 46(5): 511-526.

22. Kocaefe, D., Poncsak, S., Dore, G., Younsi, R., 2008: Effect of heat treatment on the wettability of white ash and soft maple by water. HolzalsRoh- und Werkstoff66: $355-361$.

23. Kubojima, Y., Okano, T., Ohta, M., 1998: Vibrational properties of Sitka spruce heat-treated in nitrogen gas. Journal of Wood Science 44: 77-37.

24. Lee, S.H., Ashaari, Z., Lum, W.C., Halip, J.A, Ang, A.F., Tan, L.P., Chin, K.L., Tahir, P.M., 2018: Thermal treatment of wood using vegetable oils: A review. Construction and Building Materials 181: 408-419.

25. Lin, B.J., Colin, B., Chen, W.S., Petrissans, A., Rousset, P., Petrissans, M., 2018: Thermal degradation and compositional changes of wood treated in a semi-industrial scale reactor in vacuum. Journal of Analytical and Applied Pyrolysis 130: 8-18. 
26. Ling, Z., Ji, Z., Ding, D., Cao, J., Xu, F., 2016: Microstructural and topochemical characterization of thermally modified poplar (Populuscathayaha) cell wall. BioResources 11(1): 786-799.

27. Mburu, F., Dumarcay, S., Huber, F., Petrissans, M., Gerardin, P., 2007: Evaluation of thermally modified Grevillarobusta heartwood as an alternative to shortage of wood resource in Kenya: Characterisation of physicochemical properties and improvement of bio-resistance. Bioresource Technology 98: 3478-3486.

28. Sailer, M., Rapp, A.O., Leithoff, H., Peek, R.D., 2000: Upgrading of wood by application of an oil heat treatment. HolzalsRoh- und Werkstoff58: 15-22.

29. Schwanninger, M., Rodrigues, J.C., Pereira, H., Hinterstoisser, B., 2004: Effects of short-time vibratory ball milling on the shape of FT-IR spectra of wood and cellulose. Vibrational Spectroscopy 36: 23-40.

30. Segal. L., Creely, J.J., Martin, A.E., Conrad, C.M., 1959: An empirical method for estimating the degree of crystallinity of native cellulose using the X-ray diffractometer. Textile Research Journal 29(10): 786-794.

31. Tang, T., Chen, X., Zhang, B., Liu, X., Fei, B., 2019: Research on the physico-mechanical properties of moso bamboo with thermal treatment in tung oil and its influencing factors. Materials 12(4): 599.

32. Tjeerdsma, B.F., Militz, H., 2006: Chemical changes in hydrothermal treated wood: FTIR analysis of combined hydrothermal and dry heat-treated wood.HolzalsRoh- und Werkstoff63: 102-111.

33. Traoré, M., Kaal, J., Cortizas, A.M., 2018: Differentiation between pine woods according to species and growing location using FTIR-ATR. Wood Science and Technology 52: $487-504$.

34. Wang, J.Y., Cooper, P.A., 2005: Effect of oil type, temperature and time on moisture properties of hot oil-treated wood. HolzalsRoh- und Werkstoff63: 417-422.

35. Wang, X.H., Fei, B.H., Liu, J.L., 2014: Effect of vacuum heat treatment temperature on physical and mechanical properties of Eucalyptus pellita wood. Wood and Fiber Science. 46(3): 368-375.

36. Welzbacher, C.R., Wehsener, J., Rapp, A.O., Haller, P., 2008: Thermo-mechanical densification combined with thermal modification of Norway spruce (Piceaabies Karst.) in industrial scale- Dimensional stability and durability aspects. HolzalsRoh- und Werkstoff66: 39-49.

37. Welzbacher, C.R., Rassam, G., Talaei, A., Brischke, C., 2011: Microstructure, strength and structural integrity of heat-treated beech and spruce wood. Wood Material Science and Engineering 6: 219-227.

38. Yildiz, S., Gümüskaya, E., 2007: The effects of thermal modification on crystalline structure of cellulose in soft and hardwood. Building and Environment 42: 62-67.

39. Yun, H., Tu, D., Li, K., Huang, J., Ou, L., 2015: Variation and correlation of heat-treated wood's crystalline structure and impact toughness. BioResources 10(1): 1487-1494. 
Intan Fajar Suri, Byantara Darsan Purusatama, Seung Hwan Lee, Nam Hun Kim*

Kangwon National University

College Of Forest And Environmental Sciences

Department Of Forest Biomaterials Engineering

Chuncheon 2434I

Republic Of Korea

*Corresponding author: kimnh@kangwon.ac.kr

Wahyu Hidayat

University OF LAMPUng

Faculty Of Agriculture

Department Of Forestry

BANDAR LAMPUNG 35I45

INDONESIA

Shalehudin Denny Ma'ruf

University OF LAMPUNG

Environmental Science Master Study Program

BANDAR LAMPUNG 35I45

INDONESIA

Fauzi Febrianto

IPB UNIVERSITY

Faculty Of Forestry

Department Of Forest Products

BOGOR I6680

INDONESIA 
